\title{
Diversity in Election Administration: Understanding and Serving Your Voters
}

\author{
Lauri Ealom
}

\begin{abstract}
Successful election administration requires that election administrators not only know and follow the appropriate local, state, and federal policies but also understand the population of constituents they serve. Across the field, there is considerable variation in the professional path taken to a career in election administration. This case presents the experience of one election administrator's path to election administration and the ways in which personal and professional experiences within and outside of election administration can prepare election administrators to successfully foster relationships with constituents and adopt and implement approaches to administrative decision making that engage the community; cultivating buy-in and trust.
\end{abstract}

Keywords Understanding elections • Understanding your voters

- Professional preparation $\bullet$ Experience for elections

L. Ealom $(\bowtie)$

Kansas City Board of Election Commissioners, Kansas City, MO, USA e-mail: Lauri@kceb.org

(C) The Author(s) 2019

M. Brown et al. (eds.), The Future of Election Administration, Elections, Voting, Technology, https://doi.org/10.1007/978-3-030-18541-1_8 
During college I worked as a part-time event planner and after graduation I transitioned to full-time. We planned conferences, special occasion/ theme parties, luncheons, weddings, receptions, and conferences for doctors, all over the country. At the Kansas City Board of Elections (KCEB), we serve as the event planners for elections. Envision a party where you have 150 parties going on all over the city simultaneously with 230,000 partygoers. You have to provide each of the parties/locations with a waitstaff, signage, a DJ, tables chairs, and, sometimes, security. A well-planned logistical setup is required to ensure that the flow of the environment is best for all of the participants/voters. It's imperative that the location is easily accessible for all.

What we do is logistics. We plan the election from the point of origin to consumption (voting) in alignment with statutory requirements. We oversee the entire process. We create the ballot which can include issues from the state, city, and of course, candidates. We get the information about the candidates running and vet them, an effort we collaborate on with the county prosecutor to successfully complete. We make sure candidates are registered voters in the jurisdiction that they are running for office. We check the validity of the signatures provided to have candidate names and ballot issues included on the ballot. In addition to the federal and midterm elections that people are most familiar with, we also conduct and manage many types of elections. These include church elections, union elections, school board elections, statewide elections, transportation development districts and community improvement district elections, to name a few. We are always preparing-always preparing-for the next task just as life prepares you for where you are going.

I grew up in Kansas City. It was the 1970s and I was one of two minority students in my elementary school. In that environment, I learned how to navigate in adversity. I think that is what made me who I am. I see color. I see differences, but that does not inhibit me from really wanting to get to know people and embrace everyone's differences. I learned that at a very young age and I am grateful for that experience. When I was younger, I wondered why my parents would move me to a place where there was only one person who looked like me. As a teenager I recognized it was one of the most valuable experiences I've ever had. It taught me how to be, who I am, and how to reach across the table even though you may be different. It is a skill that is invaluable in my current position.

In this industry, it's about all the different political parties. I represent the Democratic Party but I reach across the table and I'm able to work with all the parties. It is my desire to know and understand people. That 
desire is what drove me as I moved on to college and into my professional life and it continues to this day. When it was time to go to college, I chose Clark Atlanta University (formerly Clark College) a Historically Black College or University (HBCU) in Atlanta, Georgia. I chose Clark Atlanta University (CAU) because I had spent most of my life around people that were not like me. I knew that in order to be a well-rounded person, I needed to be around kids like me who had similar backgrounds, core values, and home environments.

After I graduated from CAU, I was a lobbyist for Ford where I was highly engaged in a lot of legislative efforts; things that were not in keeping with who I am. I felt like I wasn't helping anybody, I was merely helping the company. One part of my job that I really enjoyed was the management of the endowment fund. That responsibility allowed me to make large donations and participate in community engagement. At one point, they closed the Kansas City office and I went to the Union Station office to work in communications and marketing, I was there for six months and was laid off due to budgetary constraints. I then moved to New York. I stayed there, working for a record label with one of my friends from CAU, until my mother became ill. I moved back to Kansas City several days prior to 9/11. When I returned to Kansas City, I became interested in human behavior. I was hired as a Qualified Mental Retardation Professional, QMRP. I created plans that helped home care providers understand how to provide the person they were taking care of with the best quality of life experience. I felt like I had a special gift with people who had special needs. That experience allowed me to tap into a different side of myself. I became more compassionate and less spoiled. I saw people who were less fortunate than myself in a different light. From there, I went into education. I was a college guidance counselor at Frontier School of Excellence. Initially, I was hired as a kindergarten teacher and shortly after was moved to the high school. While there, I created a library, Leaders-RReaders program, formed a campus chapter of the College Leadership Readiness and Preparedness program, and served as the chair for National Honor Society. In this role, I continued to think about human behavior as I worked with some students that others found to be challenging. What I learned is that every place that you touch, every environment that you experience is preparing you for where you are going or are supposed to be.

While I was there, one of the things I realized was that the environment was very political. The international teachers could speak their native language, but the students were forbidden to speak their native tongue. Of course, I didn't agree with that nor did I agree with most of the rules set 
forth by my international colleagues. I was always ready to express my objections. After seven years, I left the school. I didn't want to work anywhere that the children were looked at as merely numbers. While working at the school I took the children home with me: their issues, their challenges. There were students who took their lives. On one occasion, I didn't check my mailbox at school and one of the students who committed suicide had left me a note. I didn't think I was cut out for this. I enjoyed teaching and working with the students, but the day to day was draining on me. I loved the students but it was too much and I was looking forward to something that would allow me to release as opposed to internalize.

One of my friends was opening a sports bar so I dusted off my college bartender hat and agreed to tend the bar. While I was working at the bar, I was able to talk with retired police chiefs, retired firemen, up-and-coming elected officials-I got to be in an environment where I could have open conversations with a variety of public administrators and elected officials who make decisions for our city. Although I had started working at the Election Board as seasonal staff, nobody knew this and being in the bar I was able to engage in open conversation that otherwise may not have happened.

As seasonal staff, I initially worked in Voter Services, which is the first line of communication to the voter. Working at the Board allowed me to see the other side of elections. With my experience as a lobbyist, I knew how to conduct legislative rewrites, talk to attorneys, go to the capital in Missouri and other states, but at the Election Board I got to see everything from start to finish. I kind of became an elections junkie-a nerd. We had an area called the "fishbowl" where the seasonal staff worked and there would often be opportunities to volunteer to do things other than what we were assigned to do. When these opportunities arose, I was always first to volunteer. This was a very busy time because of the 2012 presidential election. I worked at KCEB for three election cycles before receiving an offer in April of 2013 to work in the Finance Department. Working there allowed me to see how the election is paid for from the state allocation to the city and county's financial responsibility. I learned the intricate financial process that makes elections possible. I was intrigued and began to interview for other permanent positions.

At that time, we did group interviews. During one of them, I was asked, "Where do you see yourself in five years?" I replied, "I'd like to be the Democratic Director." My response was not well received. After the interview, I spoke to the supervisor who told me that nobody liked my answer and that I was cocky. However, five years and three months later I became the Democratic Director. 
Being interested in individuals and who they are enhances my ability to best serve voters. Understating whom you are serving, particularly as it relates to thinking about ways to help citizens understand how to vote and the power of the vote, is especially important. During the 2018 midterm election I made a list of issues that are affected by voting to counteract the, "Why should I vote?" question which is regularly posed to me when I tell people what I do or am engaged in outreach. I also like to remind people that voting is an opportunity for you to express your pleasure or displeasure with a candidate, an issue, the condition of something (i.e. public schools, streets, programs, etc.). It is the way to ensure that your opinion is counted.

Another example of how I try to meet the needs of my voters and potential voters where they are is through our decision-making process. We recently purchased new voting machines. They were rolled out in April 2018. We also purchased new poll pads (iPads tailored for voter check-in) and used them for the first time in October 2017 for a transportation development district election. Before we purchased the new equipment, we had equipment demonstrations because when we were deliberating the purchase, I didn't think it was my place to make the final decision for the voters. So, because we are spending taxpayer dollars and are here to serve the taxpayer, we provided residents with the opportunity to test out the potential equipment through demonstrations that were set up across the city. The demonstrations allowed the constituents to touch the equipment they were potentially going to use and contribute to the process that determined the equipment that was purchased. This approach has been very effective. Through the demonstrations, we also provided them with the ability to see the results of their participation.

In addition to the voting machines and poll pads, we have a new ballot marking device that eliminates the voter's need to fill in the oval to make their selection. At the end of the process, voters are presented a summary where they are alerted to races and issues they may have skipped and their overall selections. After viewing the summary, they have the option to go back and make changes or proceed with printing the ballot and feeding it into the scanner. The image that voters see after they have submitted the ballot was selected by the voters during our equipment demonstrations; it's a graphic of the Union Station Clock. ${ }^{1}$

\footnotetext{
${ }^{1}$ Although we have purchased the new equipment, we continue to have demonstration machines available for voters to use and ensure they are acclimated to the equipment and will not be dissuaded from voting because of it.
} 
To be an effective election administrator, you have to know your voters and implement new innovations to serve them. You have to leave your bias and policy preferences at the door. You have to go to the voters. You have to present information in a way that it can be received and understood. You have to know yourself well enough to be comfortable entering spaces where because of who you are, the voters may or may not want you there. You have to demonstrate to the voters that you value them and their input. You have to be comfortable in the uncomfortable because you are there to serve the voters, not yourself.

Open Access This chapter is licensed under the terms of the Creative Commons Attribution 4.0 International License (http://creativecommons.org/licenses/ by $/ 4.0 /)$, which permits use, sharing, adaptation, distribution and reproduction in any medium or format, as long as you give appropriate credit to the original author(s) and the source, provide a link to the Creative Commons licence and indicate if changes were made.

The images or other third party material in this chapter are included in the chapter's Creative Commons licence, unless indicated otherwise in a credit line to the material. If material is not included in the chapter's Creative Commons licence and your intended use is not permitted by statutory regulation or exceeds the permitted use, you will need to obtain permission directly from the copyright holder.

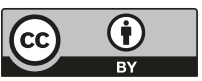

